\title{
VARIATIONS IN THE SLIDING OF A TEMPERATE GLACIER
}

\author{
By Steven M. Hodge* \\ (Geophysics Program, University of Washington, Seattle, Washington 98195, U.S.A.)
}

Abstract. Detailed measurements of the positions of stakes along the center-line of the lower Nisqually Glacier were made over a period of two years. Variations in the basal sliding speed were calculated from the measured changes in surface speed, surface slope, and thickness, using the glacier flow model of Nye $(1952)$ and allowing for the effect of the valley walls, longitudinal stress gradients, and uncertainties in the flow law of ice. The flow is predominantly by basal sliding and has a pronounced seasonal variation of approximately $\pm 25 \%$. Internal deformation contributes progressively less to the total motion with distance up-glacier. Neither the phase nor the magnitude of the seasonal velocity fluctuations can be accounted for by seasonal variations in the state of stress within the ice or at the bed, and the variations do not correlate directly with the melt-water discharge from the terminus. A seasonal wave in the ice flow travels down the glacier at a speed too high for propagation by internal deformation or the pressure melting/enhanced creep mechanism of basal sliding.

The rate of sliding appears to be determined primarily by the amount of water in temporary storage in the glacier. The peak in sliding speed occurs, on the average, at the same time as the maximum liquid water storage of the South Cascade Glacier. The data support the idea that glaciers store water in the fall, winter and spring and then release it in the summer. This temporary storage may be greatest near the equilibrium line. The amount of stored water may increase over a period of years and be released catastrophically as a jökulhlaup. Any dependence of sliding on the basal shear stress is probably masked by the effect of variations in the hydrostatic pressure of water having access to the bed.

RÉsumé. Variations dans le glissement d'un glacier tempéré. Des mesures détaillées des positions de balises le long de la ligne centrale de la partie inférieure du Nisqually Glacier ont été faites au cours d'une période de deux ans. Les variations dans le glissement à la base ont été calculées à partir des changements mesurés dans la vitesse de surface, la pente de la surface et l'épaisseur, en se servant du modèle d'écoulement des glaciers de Nye (1952) et en tenant compte, pour l'effet des parois de la vallée, des gradients de constrainte longitudinale, et des incertitudes sur le type de loi d'écoulement de la glace. L'écoulement se fait surtout par glissement à la base et présente une variation saisonnière prononcée d'environ $25 \%$. Le déformation interne contribue de moins en moins au mouvement total quand augmente la distance au haut du glacier. Ni la phase, ni la valeur des variations saisonnières de vitesse ne peuvent être expliquées par des variations saisonnières dans l'état de contrainte à l'intérieur de la glace ou sur le lit, et les variations ne sont pas directement corrélées avec les débits d'eau de fusion à la langue. Une onde saisonnière dans l'écoulement de la glace, parcours le glacier vers le bas avec une vitesse trop élevée pour être explicable comme une propagation par déformation interne ou comme le mécanisme de rampement, accéléré par la pression de l'eau de fusion qui constitue le glissement à la base.

La vitesse de glissement apparaît comme déterminée d'abord par la quantité d'eau temporairement stockée dans le glacier. La pointe dans la vitesse de glissement se produit, en moyenne, au même moment que le stock maximum d'eau liquide dans le South Cascade Glacier. Les données sont compatibles avec l'hypothèse que les glaciers emmagasinent de l'eau en automne, en hiver et au printemps, et puis la libèrent brusquement en été. Ce stockage peut être maximum près de la ligne d'équilibre. La quantité d'eau emmagasinée peut croître pendant une période de plusieurs années et être alors libérée de manière catastrophique en une vidange brusque (jökulhlaup). Toute influence de la contrainte basale de cisaillement sur le glissement est probablement masquée par l'effet des variations de la pression hydrostatique de l'eau ayant accès au lit.

Zusammenfassung. Schwankungen im Gleiten eines temperierten Gletschers. Über einen Zeitraum von zwei Jahren wurde die Lage von Pegeln entlang der Achse des unteren Nisqually Glacier beobachtet. Aufgrund des Gletscherfliessmodells von Nye (1952) und unter Berücksichtigung der Wirkung der Talflanken, der Längsspannungsgradienten und der Unsicherheiten im Eisfliessgesetz wurden Schwankungen in der Gleitgeschwindigkeit an der Unterseite des Gletschers aus den gemessenen Änderungen der Oberflächengeschwindigkeit, der Oberflächenneigung und der Eisdicke berechnet. Die Hauptkomponente des Fliessens besteht im Gleiten am Untergrund; es zeigt ausgeprägte jahreszeitliche Schwankungen von ungefähr $25 \%$. Gletscheraufwärts tragen innere Deformationen zunehmend weniger zur Gesamtbewegung bei. Weder Phase noch Grösse der jahreszeitlichen Geschwindigkeitsschwankungen können mit jahreszeitlichen Schwankungen des Spannungszustandes im Gletscher oder an seiner Sohle erklärt werden; sie sind auch nicht direkt mit dem Schmelzwasserausfluss am Gletschertor korreliert. Eine jahreszeitliche Welle in der Eisbewegung wandert gletscherabwärts mit einer Geschwindigkeit, die zu hoch ist, als dass sie mit inneren Deformationen oder dem durch Druckschmelze und forciertes Kriechen gekennzeichneten Gleitmechanismus erklärt werden könnte.

* Now at U.S. Geological Survey, Tacoma, Washington 98402 , U.S.A. 
Die Gleitgeschwindigkeit scheint hauptsächlich durch die augenblickliche Wasserhaltung des Gletschers bestimmt zu sein. Im Mittel tritt die maximale Gleitgeschwindigkeit zur selben Zeit auf wie der maximale Schmelzwassergehalt am South Cascade Glacier. Die Ergebnisse stützen die Vorstellung, dass die Gletscher im Herbst, Winter und Frühjahr Wasser speichern und dann im Sommer abgeben. Diese zeitweilige Speicherung dürfte nahe der Gleichgewichtslinie am grössten sein. Die Menge des gespeicherten Wassers nimmt möglicherweise über einen Zeitraum von Jahren zu und wird dann katastrophenartig in Form eines Gletscherlaufes freigegeben. Eine etwaige Abhängigkeit des Gleitens von der Scherspannung am Grunde wird wahrscheinlich durch die Auswirkung von Schwankungen im hydrostatischen Druck des Wassers, das zum Bett gelangen kann, überdeckt.

\section{INTRODUCTION}

Seasonal variations in the motion of a glacier have been observed many times, for example, by Forbes (1846), Agassiz (1847), Blümcke and Finsterwalder (1905), Schimpp (1958), and Elliston ([Union Géodésique et Géophysique Internationale], r963, p. 65-66). In general, spring-summer velocities in the ablation area are greater than fall-winter ones, but in the accumulation area there is either no significant variation or a variation opposite in phase to that of the ablation area. The magnitude of these variations is usually too large to be due to variations in the applied stress, and so changes in the amount of water at the glacier bed are assumed to cause the fluctuations by changing the amount of basal sliding. This hypothesis, however, has not been verified conclusively and the existing published data on seasonal velocity variations are inadequate to allow further elaboration. A detailed analysis of shortterm velocity observations of the Nisqually Glacier, Mount Rainier, Washington, was made in an attempt to fill this gap.

The full results of this study were published as a Scientific Report of the Department of Atmospheric Sciences, University of Washington, Seattle (Hodge, 1972). This paper is a condensed version of that report.

\section{The Nisqually Glacier}

The Nisqually Glacier (lat. $46^{\circ} 48.5^{\prime}$ N., long. $121^{\circ} 44.5^{\prime}$ W.) is the largest glacier on the south side of Mount Rainier (Fig. I). Excluding its major tributary, the Wilson Glacier, it has an area of $4.4 \mathrm{~km}^{2}$, an average width of $600-700 \mathrm{~m}$, and a length of $6.5 \mathrm{~km}$, and descends from an elevation of $4328 \mathrm{~m}$ to $\mathrm{I} 4 \mathrm{I} 4 \mathrm{~m}$. The upper half of the glacier has a mean slope of $30^{\circ}$, is badly crevassed in the summer, and is frequently swept by avalanches in the winter. Consequently the measurements were restricted to the lower half, where the mean slope is only $14^{\circ}$. The division between the two areas occurs $2.9 \mathrm{~km}$ from the present terminus, at an elevation of $2225 \mathrm{~m}$, and coincides approximately with the equilibrium line. Thus only the ablation area was studied (Fig. 2).

The glacier is exposed to the full force of the storm systems which move in from the Pacific Ocean to the west. The average annual snowfall is $15^{-16} \mathrm{~m}$, and by March or April there is

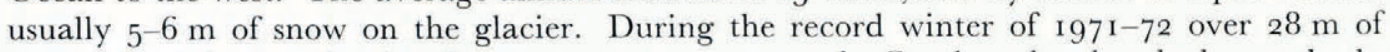
snow fell, and snow depths of over $13 \mathrm{~m}$ were measured. On the other hand, the southerly exposure and low elevation of the terminus cause heavy ablation during the summer months. Air temperatures of $20^{\circ} \mathrm{C}$ are not uncommon and the annual ice ablation near the terminus is typically $8 \mathrm{~m}$. Copious quantities of melt water are produced.

The lower Nisqually Glacier is thus a steep, fast-moving, temperate, valley glacier which undergoes annual thickness changes of the order of several per cent of its total thickness. As evident from the surface topography, the bed is complex and produces a complicated flow pattern. On the other hand, the Nisqually Glacier is one of the most accessible glaciers in the world, since a road is kept open to within $\mathrm{I} \cdot 3 \mathrm{~km}$ of the terminus all the year round. It was for this reason alone that the Nisqually Glacier was chosen. 


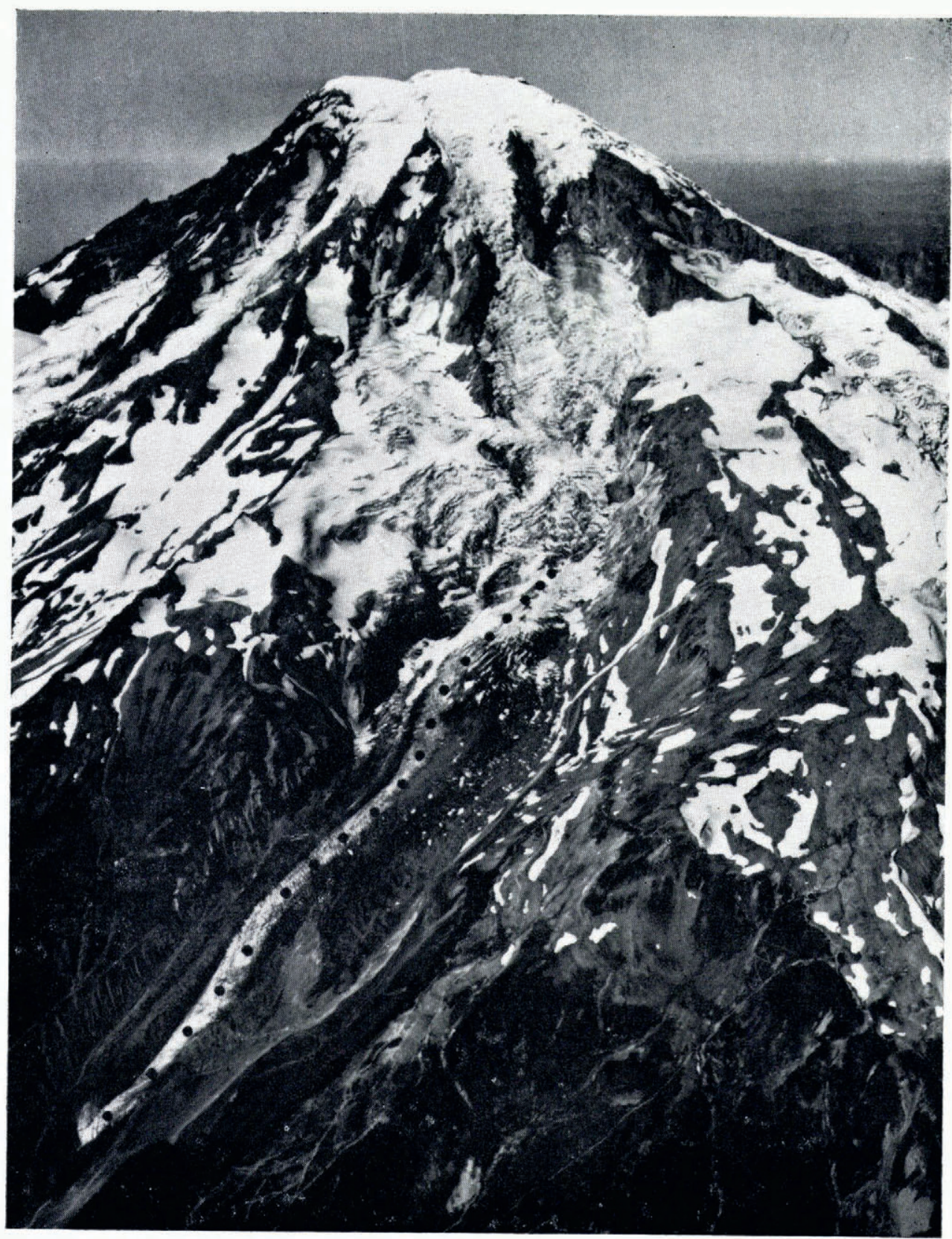

Fig. I. Oblique aerial view of the Nisqually Glacier and the south side of Mt Rainier. The dots indicate the approximate positions of the 19 movement stakes. (Photograph by Austin S. Post, 22 August Ig6g.) 


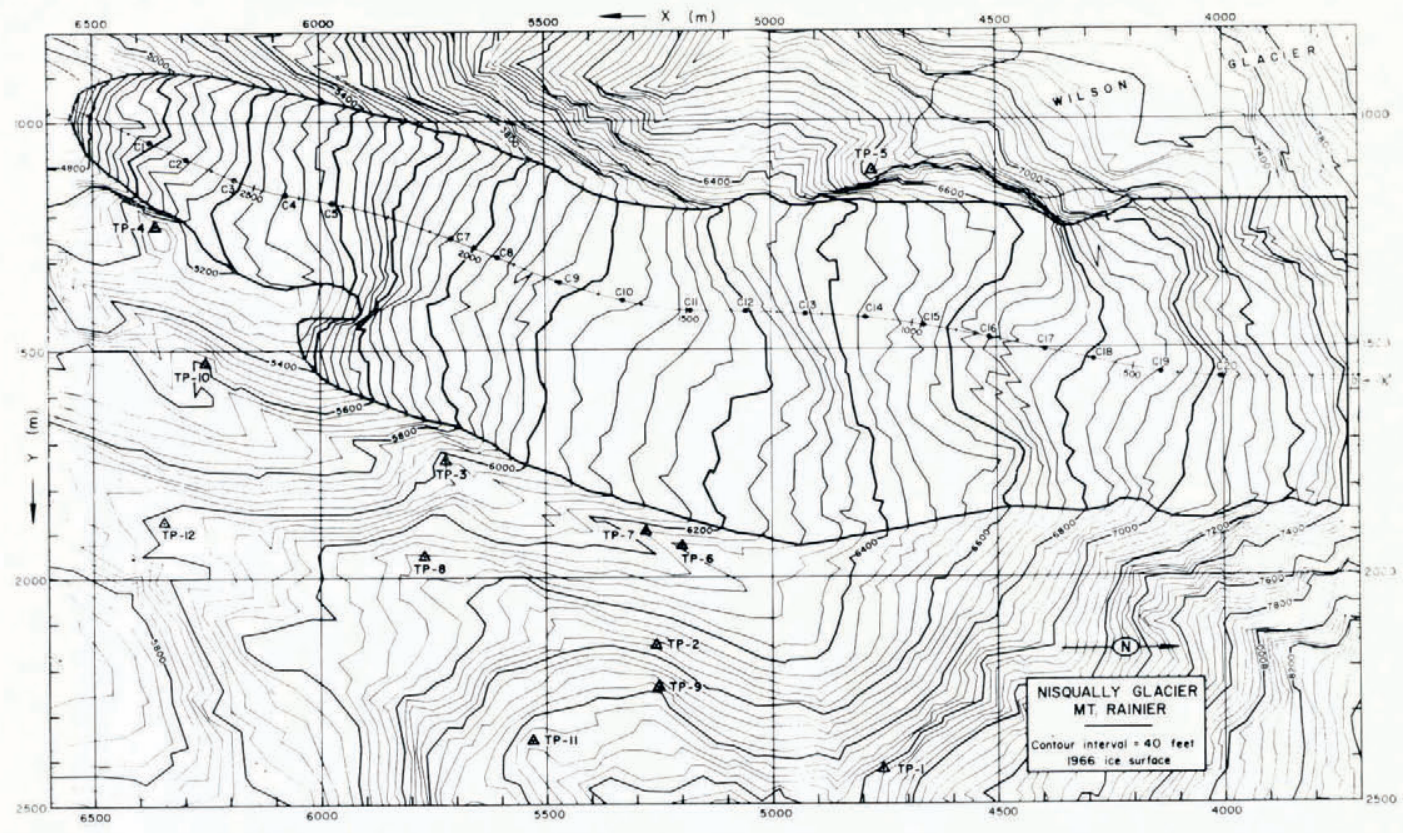

Fig. 2. Map of the lower Nisqually Glacier and the surrounding terrain. The contour interval is $12.192 m(40 \mathrm{ft})$. The grid system, the triangulation points, the movement stakes, and the curvilinear $x^{\prime}$ axis along the flow center-line are also shown. Stake C6, in the middle of a small ice fall, was abandoned as it proved too difficult to maintain. Distance along the $x^{\prime}$ axis is referred to as simply $x$ in this paper.

\section{Measurements}

Nineteen movement stakes were placed about every I 30 m down a longitudinal line along the strip of bare ice which lies approximately two-thirds of the way toward the west side of the glacier and which marks the zone of maximum surface velocity (Figs. I and 2). The stakes were placed in the ice with a steam drill (Hodge, I97I), and were made from $2 \mathrm{~m}$ interlocking sections of high-strength aluminum alloy tubing so they would not break during winter storms.

A triangulation net of 12 points was established around the lower glacier (Fig. 2); seven of these points are sufficiently windswept that they can be used throughout the year. All points were occupied and 4,6 , or 8 measurements of the horizontal and vertical angles to the remaining visible points were made. The redundancy in the angle measurements was used to adjust the net so that it satisfied the usual geometric requirements. Scale was provided by taping the distance between TP-6 and TP-7. The internal error of the net after adjustment was approximately $\pm 7 \mathrm{~mm}$, both horizontally and vertically.

All angle measurements were made with Kern DKM-2 theodolites. Horizontal and vertical angles were always recorded, and almost all measurements are an average of the "direct" and "reverse" positions of the telescope. An extensive error analysis showed that the standard deviation in a horizontal angle was $\pm 3 \cdot \mathrm{I}^{\prime \prime}$ and in a vertical angle $\pm 5 \cdot 3$ ", and that these figures probably included any atmospheric refraction effects. Any subsequent discussion of errors assumes that all angles were measured to this accuracy.

The movement stakes were surveyed from 4 June ig68 to 4 June I970. 59 successful surveys were made, an average of one every $\mathrm{i} 2 \mathrm{~d}$. The time between two successive measurements of the position of any stake varied from 6 to $73 \mathrm{~d}$ (Fig. 3). Surveys were attempted 
in the winter whenever the weather looked favorable, but nevertheless large gaps in December and January occurred. During the first winter the uppermost five stakes were demolished by an avalanche and during the second winter 13 stakes were bent over and covered in a severe riming storm. In both winters many stakes were simply buried by heavy snowfall before they could be extended.

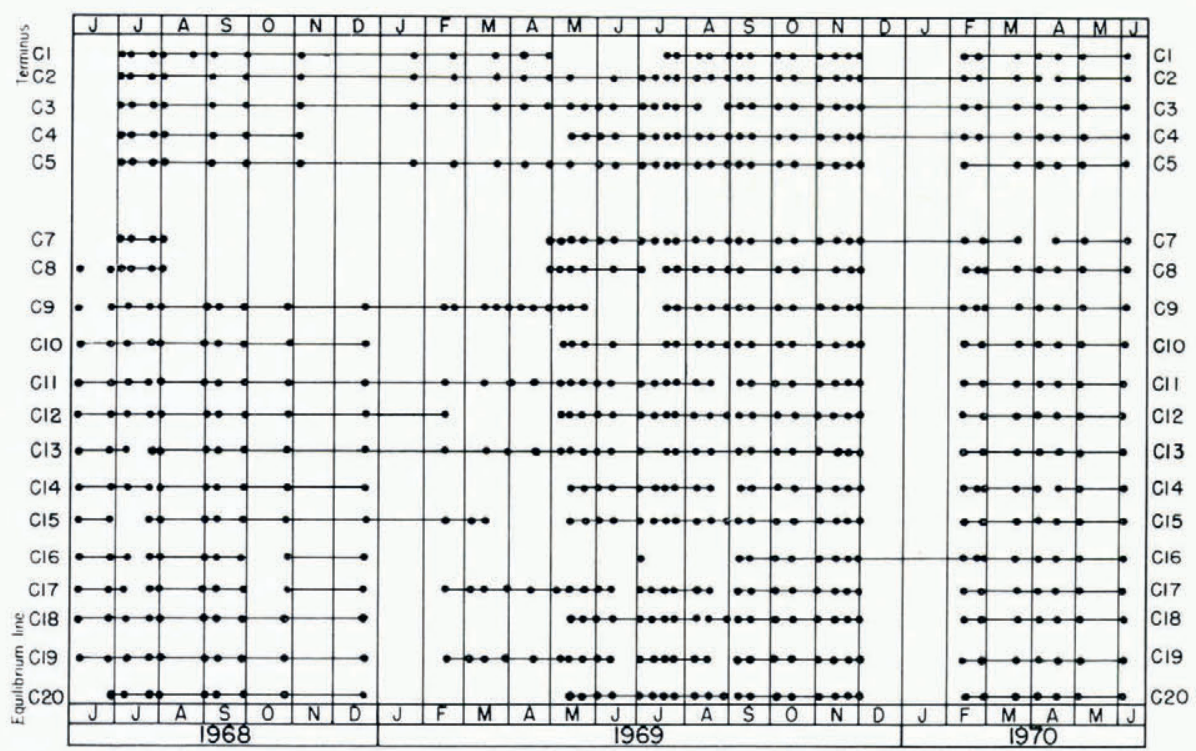

Fig. 3. The dates of the surveys of the movement stakes. Measurements later found to be faulty have been omitted. Velocities can only be calculated along the lines connecting the dots, the gaps indicating times when a stake was relocated or damaged by snowfall or avalanches.

In addition to the measurements of the stake positions, the accumulation and ablation was determined by noting the level of the ice or snow on the stake, and the run-off from the glacier was continuously recorded at a stream gage installed by the U.S. Geological Survey on the Nisqually River $\mathrm{r} .8 \mathrm{~km}$ below the terminus.

The bedrock topography was calculated from over 200 measurements of the gravity field over the glacier (Hodge, 1972). Elaborate corrections were made to compensate for the complex surface of the glacier and surrounding terrain, and the regional gravity field was determined using ice depths from areas of known bedrock (from old maps), two depths from bore-hole drilling, and gravity measurements over the terrain along the east side of the glacier. The mean thickness along the center-line of the ablation area is $70 \mathrm{~m}$. Despite the fact the Nisqually Glacier is thin and lies on the flank of a volcano the ice thicknesses are considered to be as accurate as similar measurements done previously in regions of simpler geology. The uncertainty in $h$ is estimated to be $\pm 10 \mathrm{~m}$, increasing to $\pm \mathrm{I} 5 \mathrm{~m}$ near the terminus.

\section{Calculation of the surface velocity}

Calculation of the coordinates of a point on a stake was done using standard trigonometric techniques. Calculation of the surface velocity, however, was not as straight-forward since the long metal stakes were frequently bent over during the winter by wind, riming and snowfall. The stakes would straighten up again during the ablation season. A correction for this bending was necessary (in a few situations bending of the stake between surveys even produced an apparent backward motion). 
The tilt of the straight portion of the stake protruding from the surface was calculated by sighting to two points on the stake a known distance apart. Differences in tilt between two surveys were then attributed to a bending of that portion of the stake between the two respective surface levels. Assuming the bent segment was a circular arc tangent to the adjacent segments, it was then possible to obtain a unique solution for the amount and direction of the bending between the two surveys. Experience in the field showed that only occasionally were stakes more severely contorted than implied by this assumption.

The average error in the coordinates of a point observed with the theodolite was about $\pm 30 \mathrm{~mm}$ horizontally and $\pm 20 \mathrm{~mm}$ vertically. The average error in the tilt measurements was about $\pm 2^{\circ}$ in the amount of tilt and $\pm 12^{\circ}$ in the azimuth. The resulting errors in the velocity values averaged $\pm 3 \mathrm{~mm} \mathrm{~d}^{-1}$ in the speed and $\pm \mathrm{I}^{\circ}$ in the direction; these figures include an estimate of the error in the bend corrections, obtained by assuming the difference in tilt was due to a sharp "kink" rather than a smooth circular arc. The measurement error in the speed is of the order of $\pm 1 \%$ of the total value.

The surface velocity of a glacier depends upon the time interval of observation - the shorter the time interval the greater the fluctuations in velocity (Meier, 1960). This effect, separate from the experimental error, is real and requires that the data be filtered so that they reflect only variations of a seasonal frequency. All survey pairs with intervals less than ${ }_{5} \mathrm{~d}$ were eliminated as this was the best compromise between too large a "scatter" and too many gaps in the data. Those with intervals greater than $90 \mathrm{~d}$ were also eliminated because this interval spans more than one quarter of the seasonal cycle.

In addition to this filtering, the data were also smoothed by calculating velocity values from all possible survey combinations whose time interval was in the allowed range (I 5-9o days). This increases the number of data points and, since any erroneous effects caused by a fortuitous choice of survey combinations are minimized, it has the effect of smoothing the data.

All velocity values were corrected for transverse velocity gradients. Nine transverse velocity profiles were measured in May 1970 and the resulting gradients were applied to the remaining data, assuming the gradients to be independent of time. The average correction in the speed was $1.7 \mathrm{~mm} \mathrm{~d}^{-1}$ and the maximum only $17 \mathrm{~mm} \mathrm{~d}^{-1}$. All values were corrected back to an arbitrary center-line drawn to approximate both the line of maximum speed and the mean position of the stakes (Fig. 2).

Finally, corrections for longitudinal velocity gradients were also made, the gradients being estimated from the mean longitudinal velocity profile for each month. Velocities were corrected to arbitrary "standard stake positions", defined as the average center-line positions of the stakes over the two-year period of measurements.

Applying a correction for bending of the stakes reduced the overall scatter of the velocity data points by $29 \%$. Correcting for transverse velocity gradients gave a further reduction in the scatter of only $\mathrm{I} \%$, but filtering out time intervals less than ${ }_{1} 5 \mathrm{~d}$ reduced it by $18 \%$. Eliminating faulty data points gave an additional reduction of $9 \%$, leaving the final data with $57 \%$ less scatter than the uncorrected data. ["Scatter" is defined here as the root-meansquare departure of the data points from the final curves of mean speed versus time.]

\section{Results of THE VELOcity Galgulations}

Figures 4 and 5 show the time variation of speed for two representative stakes, one near the terminus and one near the equilibrium line. The curves are drawn using data from adjacent stakes as well as data from the stake in question and they are intended to depict only the general trend of the velocity on a seasonal basis and over some general area of the glacier surrounding the stake. The higher-frequency fluctuations suggested by some of the individual data points must be ignored because of the assumptions implicit in the above smoothing procedure. By using data from adjacent stakes, smoothing is effectively accomplished with 


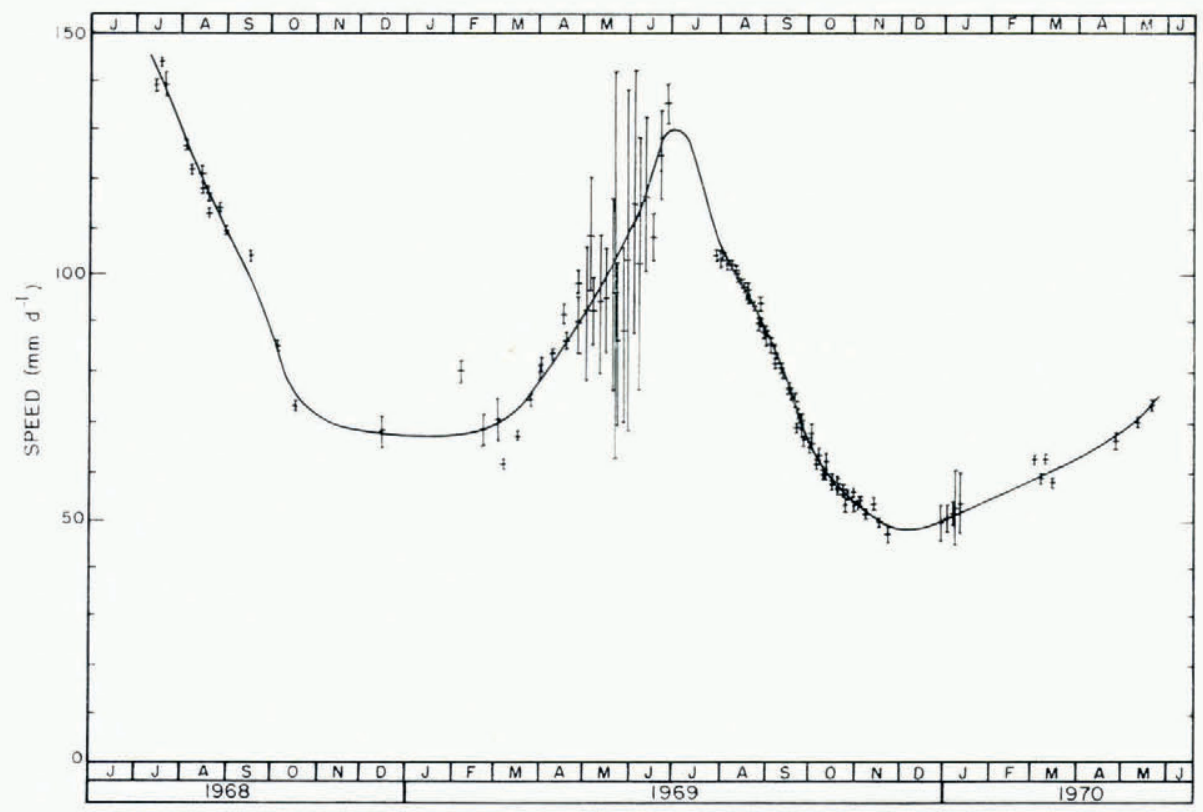

Fig. 4. The speed versus time curve for stake $\mathrm{C}_{2}$, near the terminus. The error bars are a geometric effect based on a fixed error in the angle measurements.

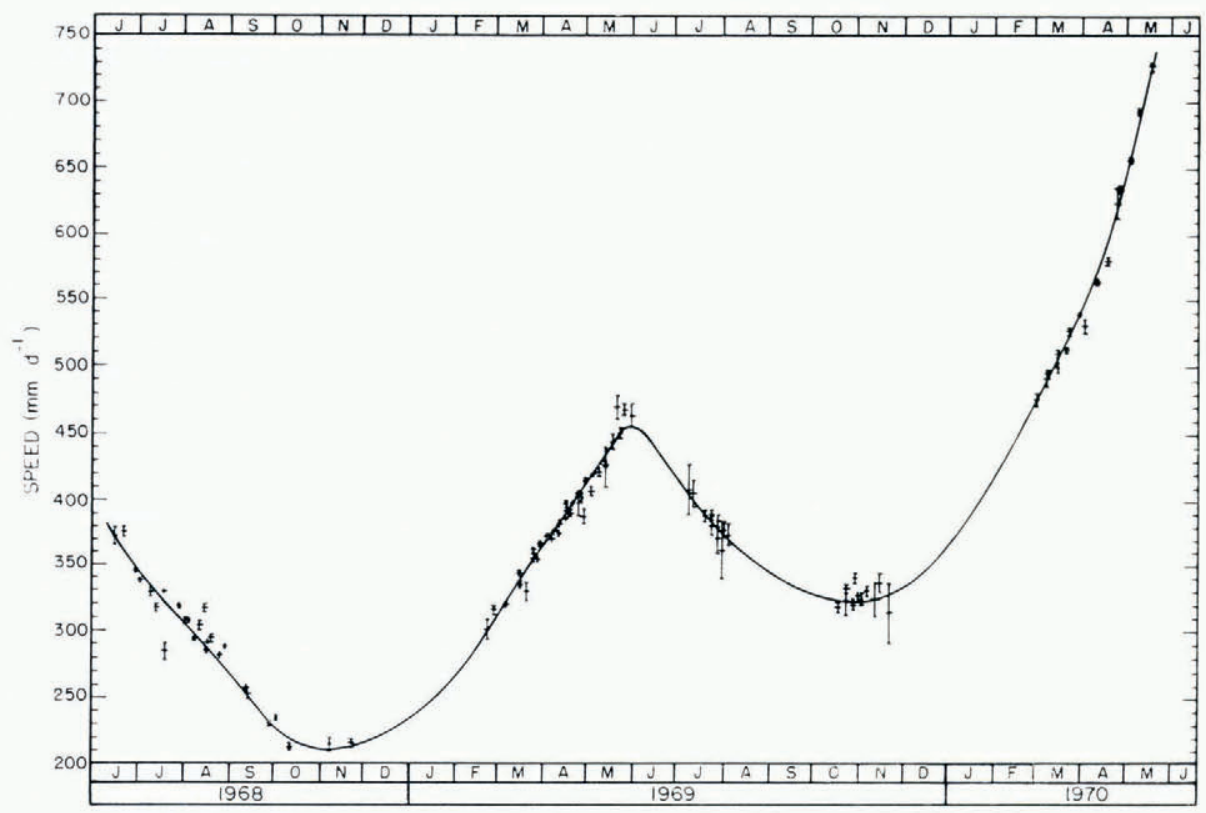

Fig. 5. The speed versus time curve for stake CIg, near the equilibrium line. The origin and scale of the speed axis is different from that in Figure 4. 


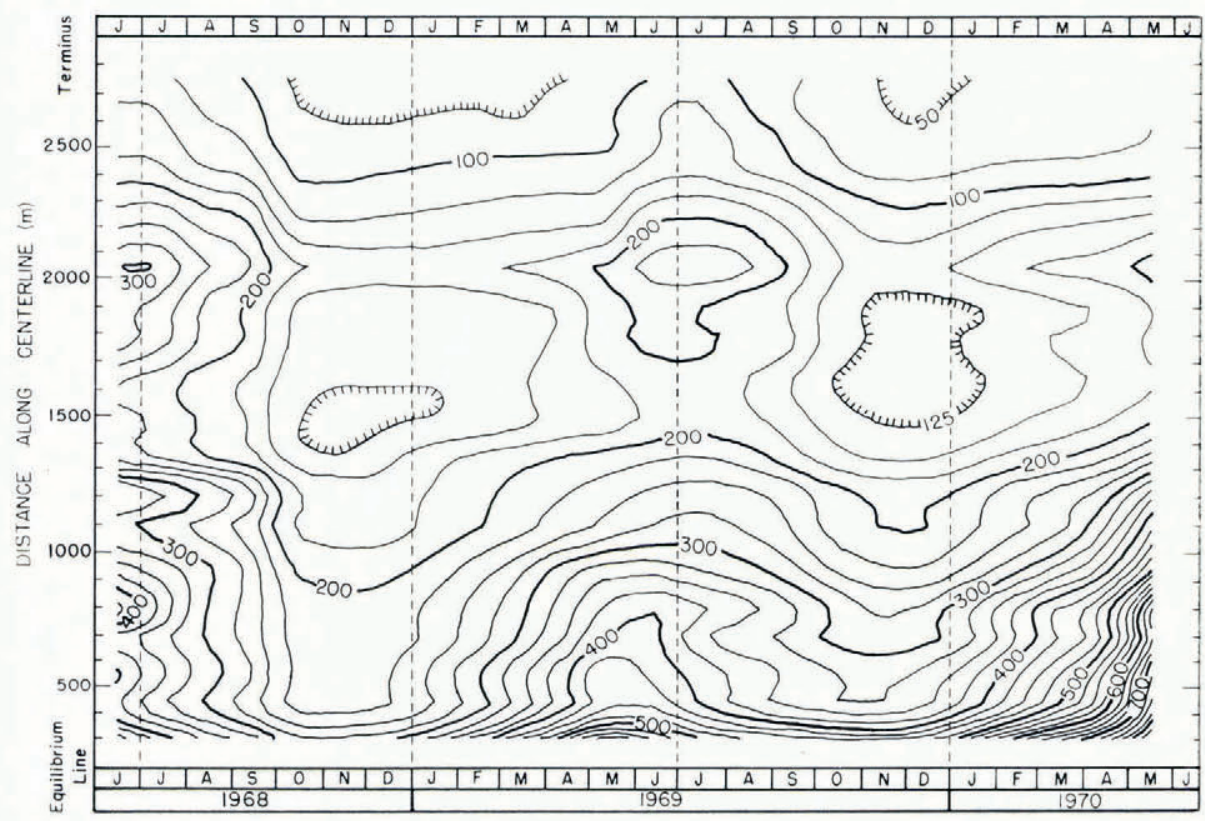

Fig. 6. The measured surface speed as a function of time and distance. The contour interval is $25 \mathrm{~mm} \mathrm{~d}^{-1}$. The maximum and minimum speeds occur progressively later with distance down-glacier; this represents a "seasonal wave" in the ice flow.

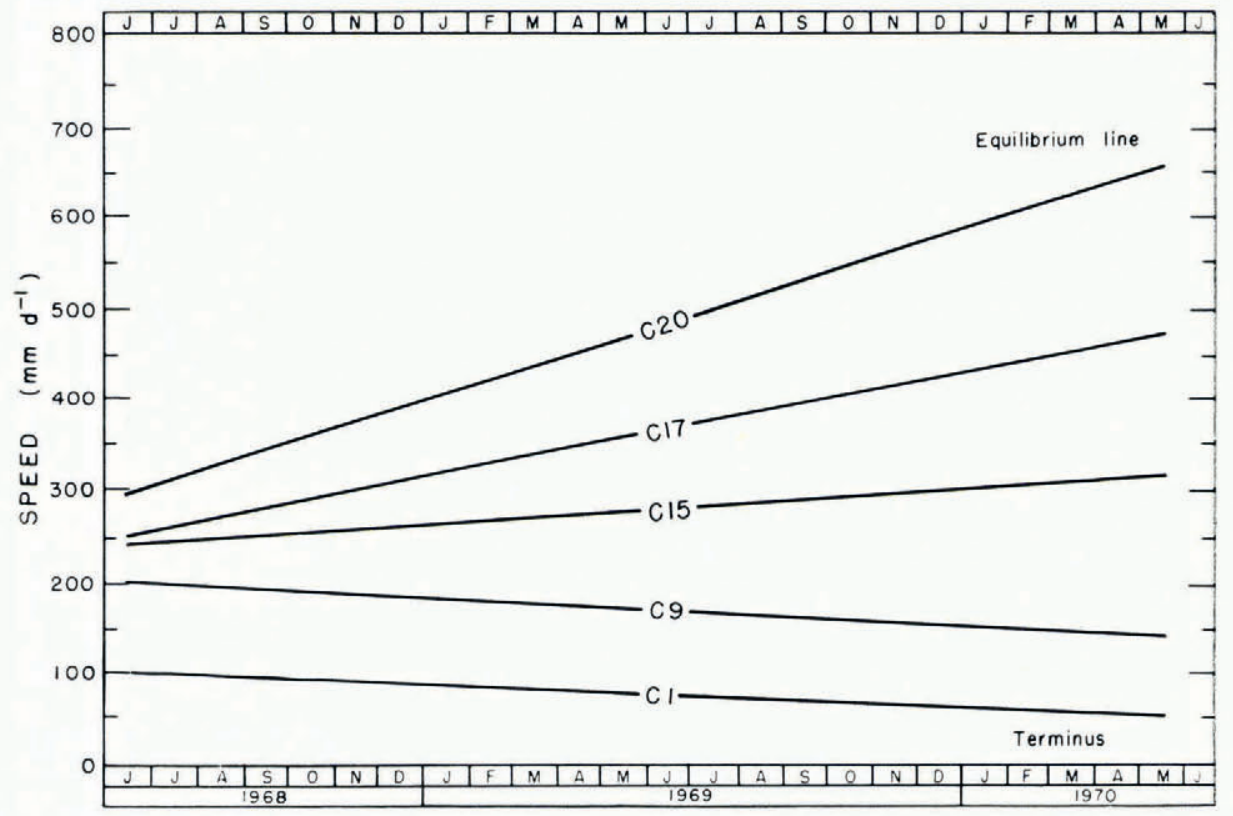

Fig. 7. The long-period trend of surface speed over the two years of measurements. 
distance as well as with time. The resulting field of smoothed surface speed, based on all the data, is shown in Figure 6.

The surface motion of the Nisqually Glacier from 1968 to 1970 shows two distinct time variations: a very pronounced seasonal fluctuation superimposed on a longer-period trend. As the observations cover too short a time period to define the form of the long-period trend satisfactorily, the simplest case-a linear variation with time-was assumed. Figure 7 shows, for selected stakes, the straight lines fitted by least-squares through the curves of speed versus time. Near the middle of the ablation zone the long-period velocity is approximately constant. Below this point it decreases with time, the speed of the lowermost stake dropping by about $50 \%$ over the two-year period. Above this point the long-period trend reverses direction, the uppermost stake more than doubling its annual speed from i 968 to I 970.

In the upper part of the ablation area, near the equilibrium line, the maximum seasonal velocity occurs in late May or June and the minimum in November. As the terminus is approached, both the maximum and minimum occur about one month later, in July and December respectively (Fig. 6). This progressive shift of the peaks with distance down-glacier represents a "seasonal wave" travelling at about $20 \mathrm{~km} \mathrm{a}^{-1}$. Such a wave has also been found on the Hintereisferner (Blümcke and Finsterwalder, I905; Schimpp, I958), and the estimated wave speed agrees well with Schimpp's results.

Figure 8 shows the deviation of the maximum and minimum velocities from the longperiod trend, as a function of distance along the glacier. The winter minima are consistently about $25 \%$ below the long-period velocity and there is no significant variation with distance along the glacier. The 1969 summer maximum is also fairly consistent. Over most of the glacier it averages about $25 \%$ above the long-period velocity, but near the terminus it increases to as much as $55 \%$. This tendency has also been found on the Saskatchewan Glacier (Meier, I96o), but there is no tendency for the velocity variations to vanish as the equilibrium

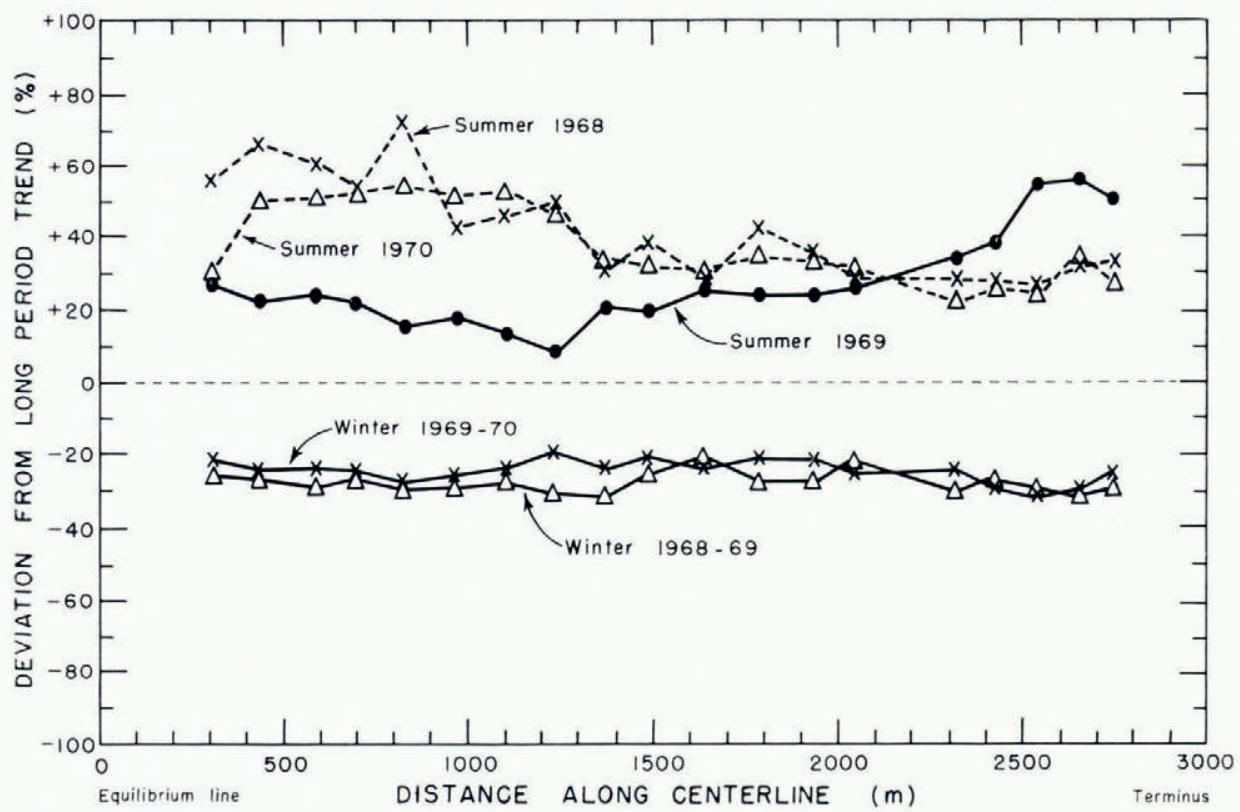

Fig. 8. The deviation of the maximum and minimum speeds from the long-period trend. The dashed lines are not as reliable as they were inferred at the beginning and end of the measurement period. 
line is approached, as noted on the Gornergletscher (Elliston, [Union Géodésique et Géophysique Internationale], I963, p. 65-66). Very definite seasonal fluctuations occurred over the entire ablation area.

The velocity of the glacier most closely equals the mean annual speed in the months of March-April and August-September. Short-term measurements of velocity made at other times of the year do not predict the mean annual speed of a glacier.

\section{Calgulation of the Sliding SPEed}

The basal sliding speed $s_{\mathrm{b}}$ was calculated from the measured surface speed $s$ using the glacier flow model of Nye (1952),

$$
s_{\mathrm{b}}=s-\frac{2 A}{n+\mathrm{I}} \tau_{\mathrm{b}}{ }^{n} h
$$

where $h$ is the center-line ice thickness (in the vertical direction), $\tau_{\mathrm{b}}$ is the basal shear stress and $A$ and $n$ are the parameters in the flow law of ice,

$$
\dot{\epsilon}=A \tau^{n}
$$

where $\dot{\epsilon}$ and $\tau$ are the effective shear strain-rate and shear stress, respectively. The basal shear stress is given by

$$
\tau_{\mathrm{b}}=f \rho g h \sin \alpha
$$

where $\rho$ is the density of glacier ice (assumed to be $0.9 \mathrm{Mg} \mathrm{m}^{-3}$ ), $g$ is the acceleration of gravity, $\alpha$ is the surface slope, and $f$ is a "shape factor" introduced to allow for the effect of the valley walls. The variables $f, \alpha$, and $h$ are smoothed over distances of $600 \mathrm{~m}$ (about eight times the ice thickness) to minimize the effect of longitudinal stress gradients (Budd, I970; Meier and others, 1974). The value of $8 h$ is a compromise between Budd's values of $10-20 h$ and a desire not to eliminate completely the details present in the original data; $8 h$ is also close to the value of $\mathrm{ioh}$ found by Meier and others for a temperate valley glacier.

Many experiments, both in the laboratory and in the field, have been done to determine the flow-law parameters $A$ and $n$. The values differ considerably, however, and there can be as much as an order of magnitude difference in the strain-rate for a given stress. All available published data and some unpublished data on the values of $A$ and $n$ were examined so that the uncertainty in the flow law could be allowed for when calculating $s_{\mathrm{b}}$. The numerical values of Nye (1953) were chosen as "average" ( $\left.A=0.173 \mathrm{bar}^{-3.07} \mathrm{a}^{-1}, n=3.07\right)$ and those of Shreve and Sharp (1970) as the "least viscous" ( $A=0.55^{\circ}$ bar $\left.^{-3.3} \mathrm{a}^{-1}, n=3.3\right)$. Most other flow law parameters, for example, Mathews (I959), Glen (I955) [quasi-viscous interpretation], Raymond (unpublished), Paterson and Savage (I963), Meier (I96o), and Kamb and Shreve (1966), are more viscous than those of Nye (1953), and so even the average flow law used here is biased to the least viscous side.

The ice thickness and surface slope are specified in the form

$$
\left.\begin{array}{l}
h(x, t)=h_{0}(x)+\Delta h(x, t), \\
\alpha(x, t)=\alpha_{0}(x)+\Delta \alpha(x, t),
\end{array}\right\}
$$

where $t$ is time and $x$ is a curvilinear distance coordinate running down the glacier center-line from the equilibrium line to the terminus (Fig. 2). $h_{0}$ and $\alpha_{0}$ were calculated from the last available map of the Nisqually Glacier (1966) and from the bedrock topography determined by gravimetry, bore-hole drilling, and areas of known bedrock; the results are shown in Figure 9. 


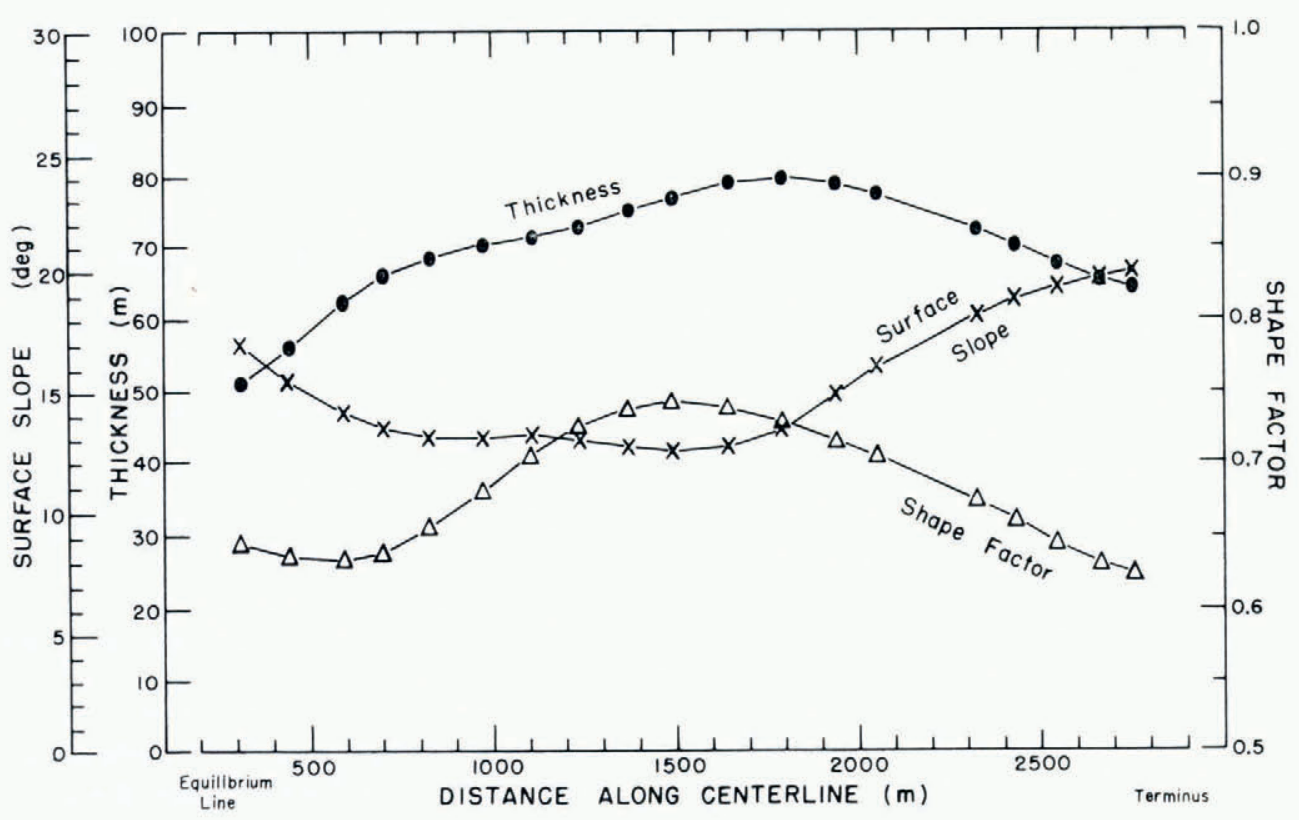

Fig. 9. The ice thickness, surface slope, and classical shape factor, calculated for the 1966 ice surface at the location of each movement stake and then smoothed using a running average over a horizontal distance of $600 \mathrm{~m}$.

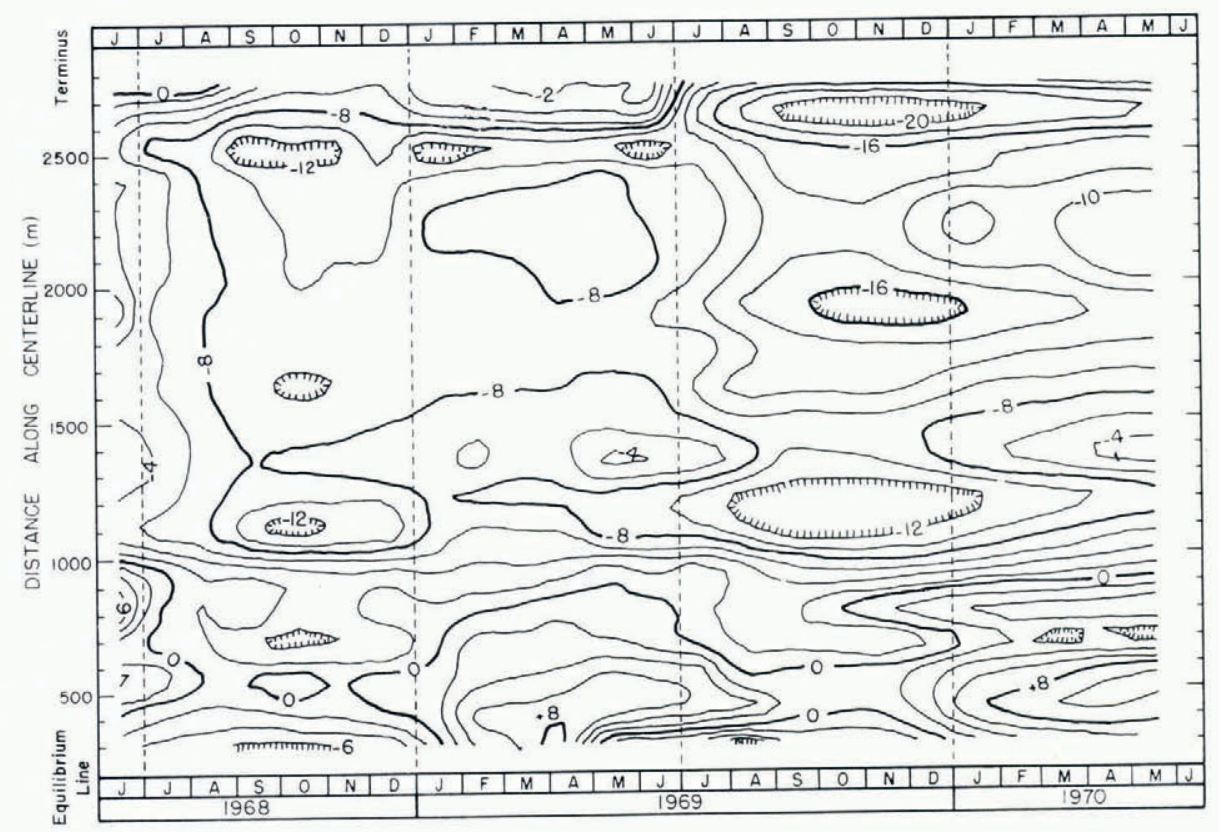

Fig. Io. The measured changes in ice thickness as a function of time and distance. The contour interval is $2 \mathrm{~m}$. Values are relative to the 1966 surface (Fig. 9). 
The changes in ice thickness $\Delta h$ were obtained from the survey measurements by correcting the surface elevation of the stakes back to fixed points in space (the standard stake positions) and converting any snow layer present to an ice equivalent. The corrections back to the fixed points were made by using the surface slopes from the I 966 map and assuming that the surface slopes are independent of time. The results are given in Figure ro. No seasonal wave in the ice thickness is evident.

The changes in surface slope $\Delta \alpha$ should, by this assumption, be zero; nevertheless the $\Delta h$ field (Fig. Io) was differentiated with respect to $x$ to see if there were any significant slope variations. The results (Fig. I I) verify that the changes in slope, if real, are generally less than $0.5^{\circ}$ and, at any rate, are predominantly with $x$ and not $t$.

Shape factors $f$ were calculated using the classical shape factor $A / P h$, where $A$ is the crosssection area and $P$ is the perimeter in contact with ice (Fig. 9). Changes in the shape factor due to changes in the ice thickness were shown to be negligible (Hodge, 1972).

The sliding speed $s_{\mathrm{b}}$ was calculated for the r 9 movement stakes and for each month of the two-year observation period. Initial results showed that the variation of $s_{\mathrm{b}}$ with distance $x$ was much greater than the variation with time $t$. Therefore values of $s_{\mathbf{b}} / s$ for each stake were averaged over the two years and plotted as a function of $x$ (Fig. 12). The results for both the average flow law and the least viscous flow law are shown, as well as the variation of basal shear stress (as calculated by Equation (3)) along the center-line.

Since the data were averaged over distances of the order of $8 h$, the sliding speed and basal shear stress also represent averages over this distance. The calculations were repeated using unsmoothed and constant variables and, as expected, only the scatter of the points in Figure 12 was affected; the overall trends with distance are the same regardless of how much or how little smoothing is done (no smoothing at all approximately doubles the scatter indicated by the stippled areas).

It is apparent that: (a) Internal deformation accounts for very little of the observed surface motion. Only with the least viscous of flow laws and only near the terminus does sliding contribute less than $50 \%$ of the surface motion. (b) Internal deformation contributes progressively less to the surface motion with distance up-glacier. Over the upper third of the ablation area, sliding accounts for well over $80 \%$ or possibly $95 \%$ - of the total motion.

The effect of uncertainties in the variables $f, \alpha$, and $h$ was examined by simultaneously perturbing them and calculating the overall effect on the average ratio $s_{\mathrm{b}} / s$. It was found that sliding contributed less than internal deformation only if (a) the ice obeys the least viscous flow law, and (b) the measured depth is everywhere too shallow by at least ro $\mathrm{m}$ and (c) the shape factors are close to unity. This, of course, is an unlikely extreme case and so it can be safely concluded that the motion of the Nisqually Glacier is dominated by basal sliding.

\section{Causes of the velocity variations}

According to existing theories, the flow of glaciers by internal deformation and basal sliding is determined by the state of stress within the ice and at the glacier bed. Variations in the flow could therefore be cause by variations in the state of stress due to changes in thickness or surface slope.

The variations in surface slope with time (Fig. I I), if they are real, are very small and could account for only a few per cent of the annual velocity variations. Furthermore, they show no obvious annual cycle and so it is concluded that surface slope changes have negligible
effect.

The variations in ice thickness with time (Fig. Io) averaged about $5 \mathrm{~m}$ between summer and winter, or about $\pm 3.6 \%$ of the average ice thickness of $70 \mathrm{~m}$. The speed due to internal deformation $s_{\mathrm{d}}$ varies as $h^{n+\mathrm{I}}$ (Equations (I) and (3)) and the sliding speed due to the pressure melting/enhanced creep mechanism as $h^{m}$, where $m=(n+\mathrm{I}) / 2$ (Weertman, 1964). For 


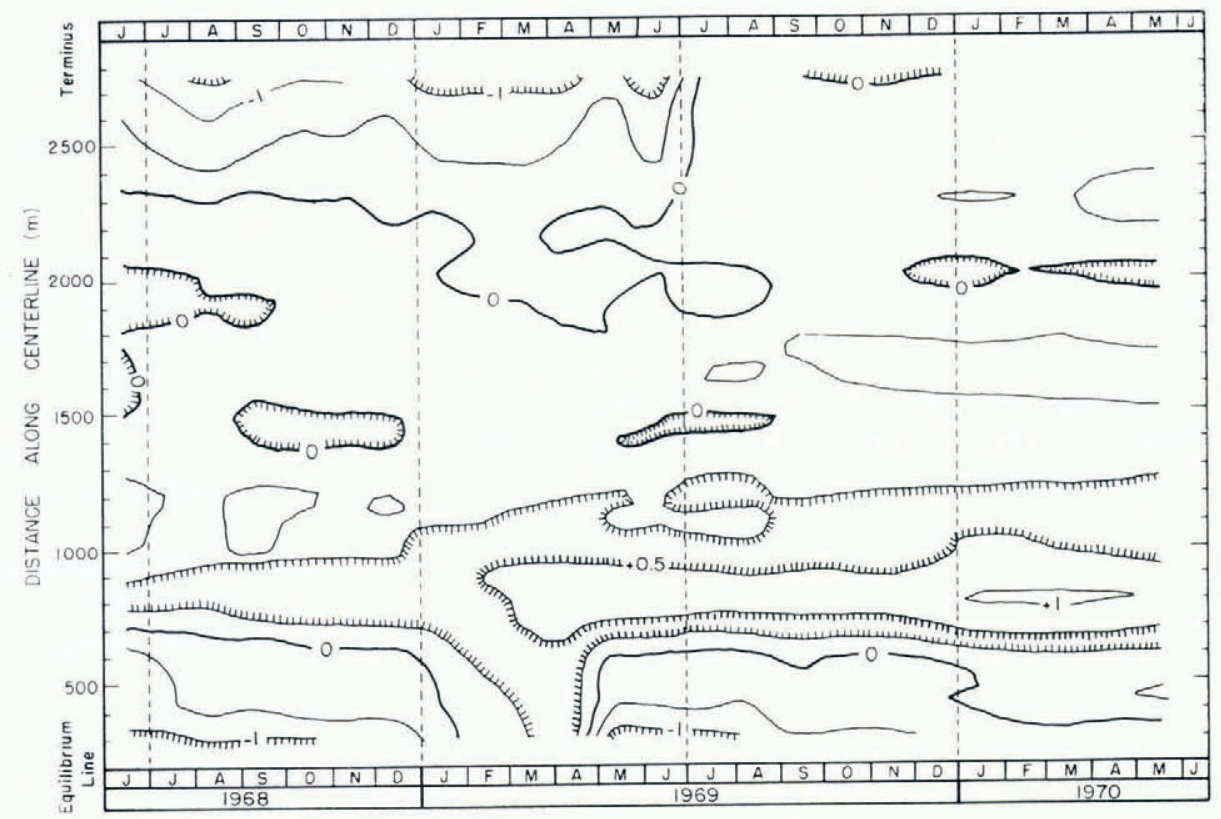

Fig. II. The changes in surface slope as a function of time and distance. The contour interval is $0.5^{\circ}$. Values are relative to the 1966 surface (Fig. 9) and were calculated by differentiation of the $\Delta h$ field (Fig. 10), using a distance interval of $600 \mathrm{~m}$.

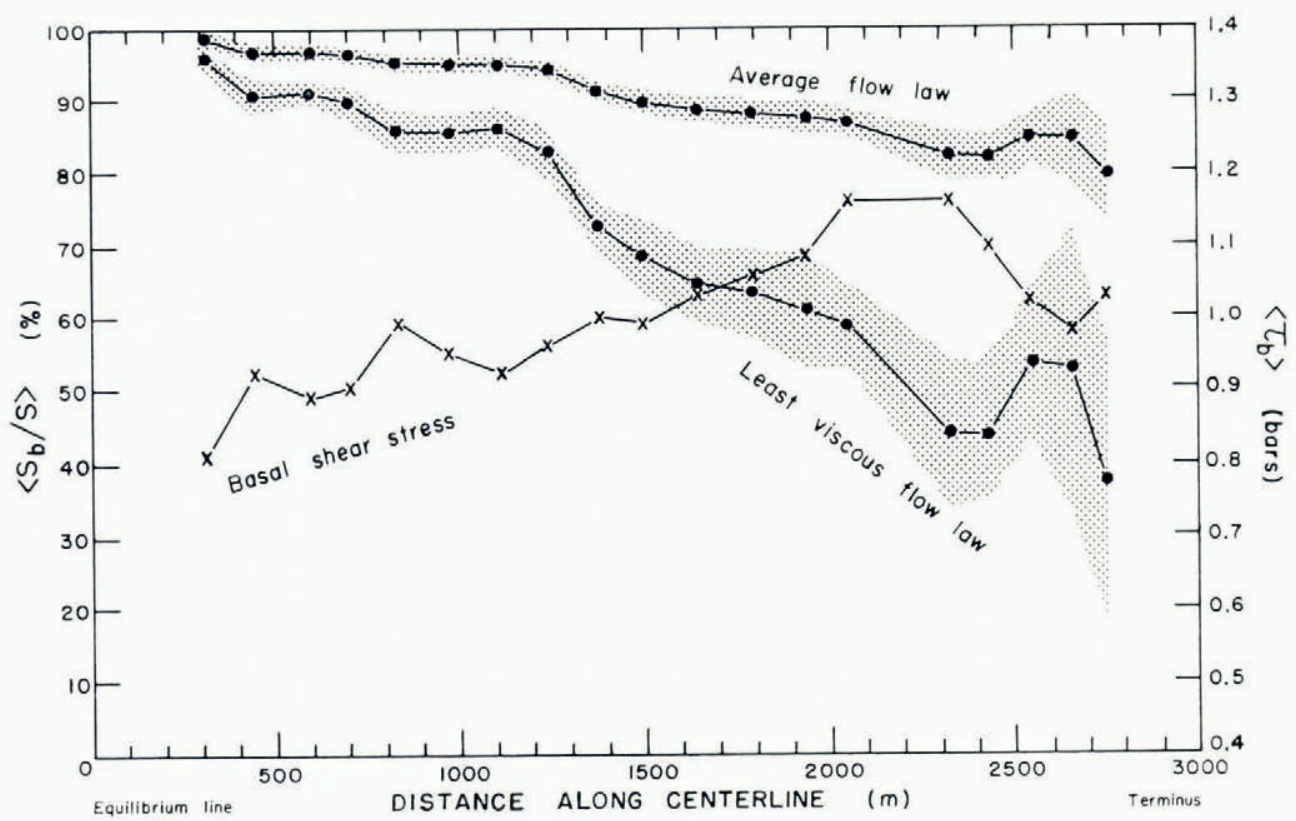

Fig. 12. The time average of the ratio of the sliding speed to the measured surface speed for the average and least-viscous flow laws. The stippled area indicates the approximate magnitude of the time variations. The basal shear stress is also shown but no time variations are indicated as they are smaller than the size of the plotting symbols. 
$n=3$ the $\pm 3.6 \%$ variation in $h$ thus implies a $\pm 1 \mathrm{I} \%$ variation in surface speed if both internal deformation and basal sliding contribute equally to the surface motion, but only $\pm 7 \%$ if internal deformation is negligible. For $n=4$, the corresponding variations in surface speed are $\pm 14 \%$ and $\pm 9 \%$. Even if it is assumed that $m=n$ instead of $(n+\mathrm{I}) / 2$, the computed variations increase to only $\pm 17 \%$ and $\pm 15 \%$, respectively, for $n=4$. Since the observed surface speed varied by at least $\pm 25 \%$ it is unlikely that variations in the state of stress (the loading effect) can account completely for the magnitude of the velocity variations.

Nor can the loading effect account for the phase of the velocity variations. In Figure 13 the mean surface speed of all the movement stakes is plotted as a function of time. As expected, the peak speed occurs in June and the minimum in November-December. However, if the mean speed due to internal deformation (which will be in phase with the mean speed due to the pressure melting/enhanced creep mechanism of basal sliding) is also plotted, we get a maximum in March-April and a minimum in October. Hence there is a phase lag of one to two months between the loading effect and the surface speed.

Consider also the seasonal wave. If this represents a normal kinematic wave, propagating along a one-dimensional glacier by either the internal deformation or the pressure melting/ enhanced creep mechanisms, it should have a wave speed given by (Paterson, i969, p. 199):

$$
c=(n+2) s_{\mathbf{d}}+(m+\mathbf{I}) s_{\mathbf{b}} .
$$

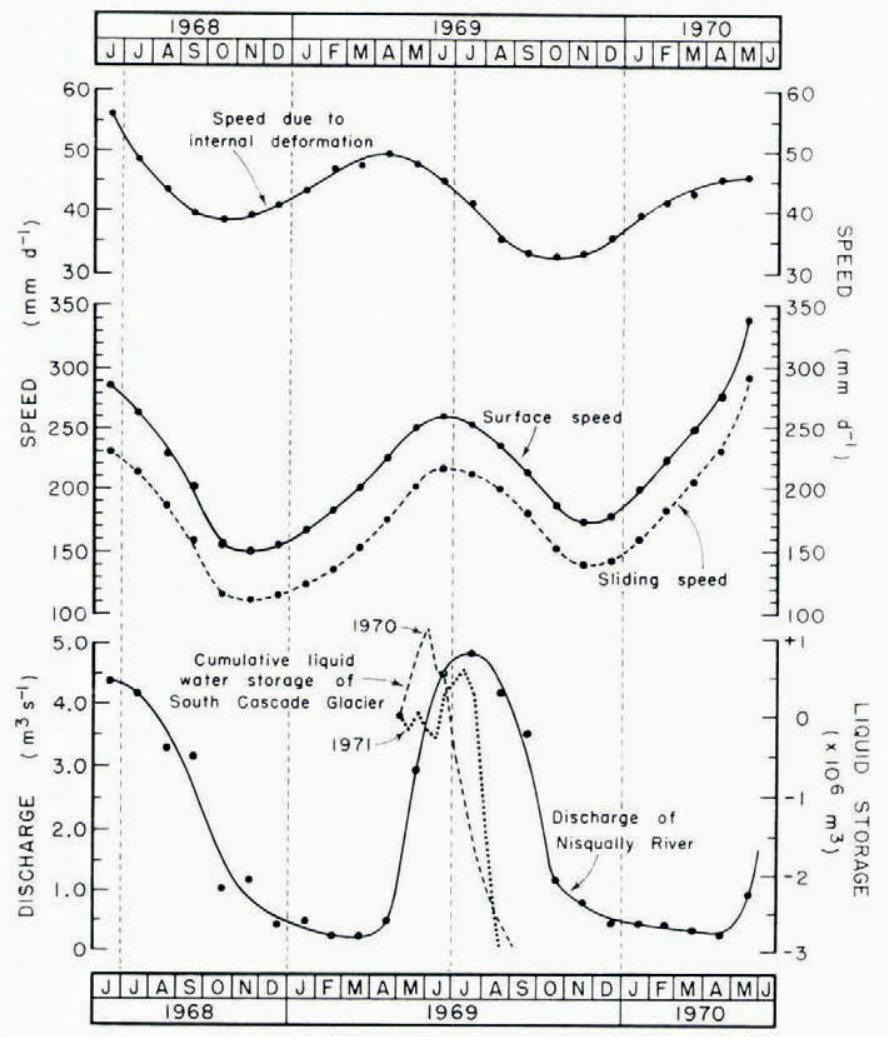

Fig. 13. The speed due to internal deformation, the measured surface speed, the sliding speed, the monthly discharge of the Nisqually River, and the cumulative liquid-water storage of the South Cascade Glacier as a function of time. The speed values are averages over all 19 movement stakes, using the average flow law in the calculations. The discharge data are accurate to about $\pm 10 \%$ at low flow and $\pm 20 \%$ at high flow. 
Since $m<n$ the wave speed is a maximum when all the measured surface speed is due to internal deformation: $c \leqslant(n+2) s$. For $n=4$ and $s=800 \mathrm{~mm} \mathrm{~d}^{-1}$ this implies $c \leqslant \mathrm{I} .8$ $\mathrm{km} \mathrm{a}^{-1}$, but for $n=3$ and $s=100 \mathrm{~mm} \mathrm{~d}^{-1}, c \leqslant 0.18 \mathrm{~km} \mathrm{a}^{-1}$. Allowing for the effect of the valley walls will reduce the value of $c$ even more (Nye, ig65). Thus the seasonal wave travels down the glacier at least one to two orders of magnitude faster than can be accounted for by assuming the ice motion is due to either of these mechanisms.

The seasonal velocity variations are therefore difficult to explain if it is assumed the ice motion is controlled by the internal deformation mechanism and/or the pressure melting/ enhanced creep mechanism of basal sliding. Instead one is led to attribute the changes in motion to the one unknown in the theories, namely the dependence of the basal sliding mechanism on the amount of water having access to the bed of the glacier. This hypothesis has been proposed before, but the data obtained on the Nisqually Glacier provide better support for it because of the detailed data reduction, error analysis and flow modelling which was done.

If the amount of water at the bed is the controlling parameter, the velocity variations might be expected to correlate with the run-off or the surface melting if one assumes that water passes through the glacier, via the bed, in a relatively short time. The monthly discharge of the Nisqually River I.8 km below the terminus is also plotted in Figure 13. The peak in the run-off occurs in July, about a month, on the average, after the peak in surface speed.* Moreover, the minimum occurs in March-April, fully four months after the corresponding minimum in the motion. For stakes near the terminus the two maxima are almost in phase but the correlation becomes progressively less valid with distance up-glacier and completely breaks down when the minima are examined. During the period November to April when the run-off is steadily decreasing, the ice is distinctly accelerating.

The results agree in part with those of Elliston ([Union Géodésique et Géophysique Internationale], r 963 , p. $65^{-66)}$, who found the velocity to be in phase with the ablation and to precede the run-off by I-2 weeks, and with those of Müller (r968), who found the movement to precede the ablation by more than a month.

The mean sliding speed (surface speed minus speed due to internal deformation) is also plotted in Figure I $_{3}$ and is in phase with the mean surface speed because internal deformation contributes relatively little to the total surface motion. Thus the loading effect does not account for this phase difference between run-off and surface speed.

Furthermore, the surface speed will not correlate with the production of water by surface melting. If it did, the peak in speed would occur progressively later up-glacier rather than the opposite. Surface melting also fails to explain the winter increase in the surface motion.

The acceleration of the glacier throughout the winter in the ablation zone is crucial to a correct interpretation of the velocity variations, since it makes it difficult to correlate the variations with run-off, surface melting or temperature. Assuming the velocity variations are due to variations in the amount of water at the glacier bed, this winter acceleration implies that the amount of water must increase during the winter, reach a peak in the late spring and early summer, and then decrease through the rest of the summer to a minimum in the fall. Presumably the larger volume of water increases the average hydrostatic pressure and thus, in turn, causes a greater area of ice to be separated from the rock, reducing the bed friction and allowing the glacier to slide faster. (Throughout this discussion it is assumed that the amount of water stored in a given vertical section of the glacier is directly related to the water pressure at the base of the section.)

Given the above hypothesis, these data thus support the concept of seasonal changes in liquid-water storage, which has been used by several workers to explain discrepancies in

* The actual peak run-off from the glacier alone was probably even later than shown on Figure I3 because low-altitude snow melt in the drainage basin occurs earlier than that of the glacier (W. V. Tangborn, personal communication, 1972). 
mass-balance measurements (Stenborg, 1970; Hoinkes, 1970; Björnsson, [1972]). In 1970, Tangborn and others (in press) made a detailed study of South Cascade Glacier to see if measurement errors could explain such discrepancies. They found instead that the mass loss calculated from run-off and precipitation measurements (the "hydrologic method") was $3^{8 \%}$ greater than that calculated from surface ablation measurements (the "glaciologic method"), and that they could not attribute this to measurement errors. They concluded the excess run-off was due to the release of liquid water from within the glacier during the summer, the extra water having accumulated in the glacier during the fall, winter and spring. The amount of the excess is estimated to reach a maximum of about $\mathrm{x} \%$ of the glacier volume.

The South Cascade Glacier is by no means identical to the Nisqually Glacier. However, this excess run-off has also been reported on glaciers in both temperate and subpolar climates. Assuming this is a general phenomenon, the cumulative liquid water storage of the South Cascade Glacier is plotted on Figure 13 for the two years 1970 and 1971 . Although it is by no means convincing proof, the storage does peak, on the average, at the same time that the surface motion does. Hence it is suggested that the seasonal variations in the velocity of a glacier are correlated not with the run-off or surface melting, but with the amount of liquid water temporarily stored within the glacier. This hypothesis could, of course, be tested more thoroughly if the storage curve could be calculated for the Nisqually Glacier, or even, for that matter, throughout the year for the South Cascade Glacier, but the necessary data do not exist and are difficult to obtain.

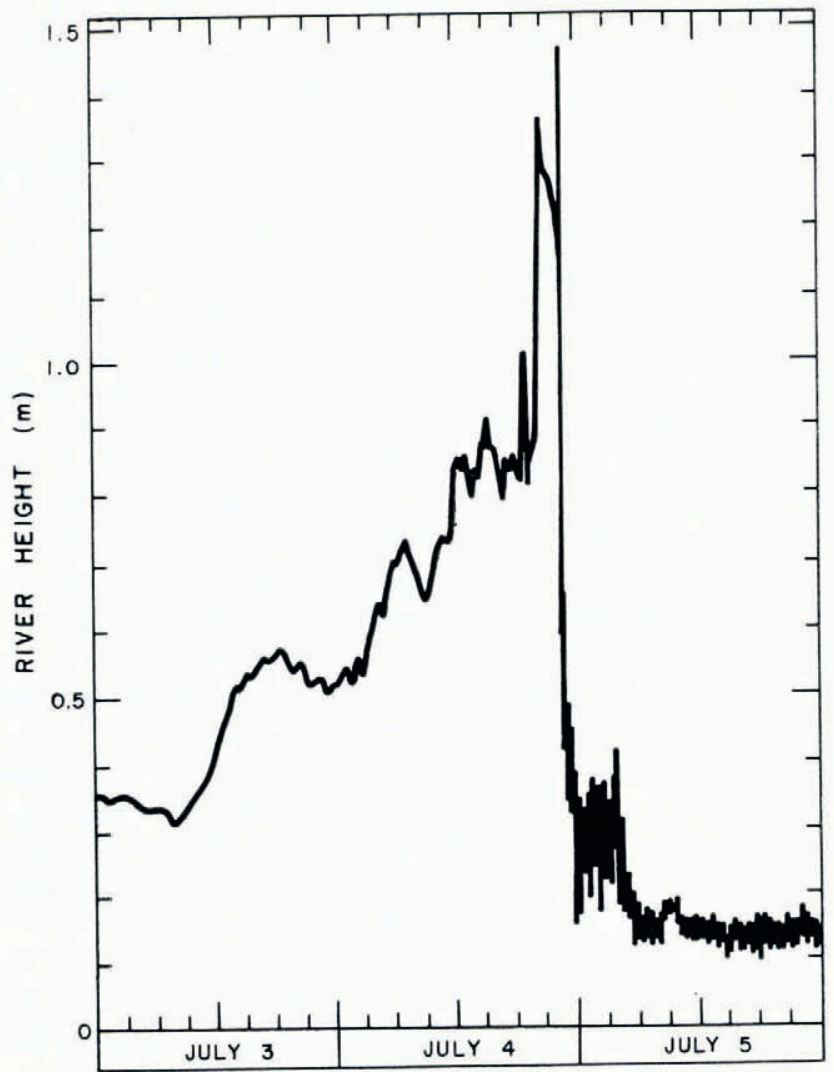

Fig. I4. The small jökulhlaup released from the Nisqually Glacier on 4 July 197o. The diagram is a direct trace of the recorder chart from the stream gage $1.8 \mathrm{~km}$ below the terminus; the origin of the ordinate scale is arbitrary. The "noise" is much greater after the flood because the bottom of the stilling well was eroded away, allowing turbulent water to enter. 
A mechanism for the storage and release of liquid water was alluded to by Stenborg (I970) and was stated more explicitly by Tangborn and others (in press). As the production of melt water decreases during the summer, the drainage channels tend to close up as the hydrostatic pressure in the water decreases and less heat is generated by viscous dissipation or carried down from the surface. Melt water and rain during the late fall, winter and early spring are insufficient to keep the passageways open against the continuously deforming ice, the discharge capacity of the drainage system is reduced and the water is delayed more and more in its passage from surface to terminus, that is, it tends to go into "storage". When melting commences in the spring the hydrostatic head of water increases rapidly, the passageways start to reopen and eventually the stored water begins to drain from the glacier. A delay between increasing water pressure and the opening of the channels is to be expected if the changes in channel size are accomplished by plastic deformation of the ice. Haefeli (1970), Shreve (1972), and Röthlisberger (1972) have discussed this problem mathematically.

A connection between liquid-water storage and the velocity of a glacier is also suggested by other data from the Nisqually Glacier. Consider the increase in long-period velocity which took place over the upper half of the ablation area (Fig. 7). Because internal deformation contributes little to the surface motion in this region, the increase in velocity must represent an increase in the sliding component. This suggests, given the above hypothesis, that there was a corresponding increase in the average annual liquid water storage, more water being stored in the glacier in the spring of 1970 than in the previous two springs. If this is true it is not surprising that a small outburst flood, or jökulhlaup, was released from the glacier in early July r970 (Fig. 14). The peak discharge was estimated (personal communication from D. Richardson, I 972 ) to be about $85 \mathrm{~m}^{3} \mathrm{~s}^{-1}$, approximately 20 times greater than the normal summer flow.

Supplementary to this are some additional velocity measurements made in May 1971. Figure I 5 shows longitudinal velocity profiles for approximately the same time of the year for each of four consecutive years. The large increase in velocity over the upper half of the

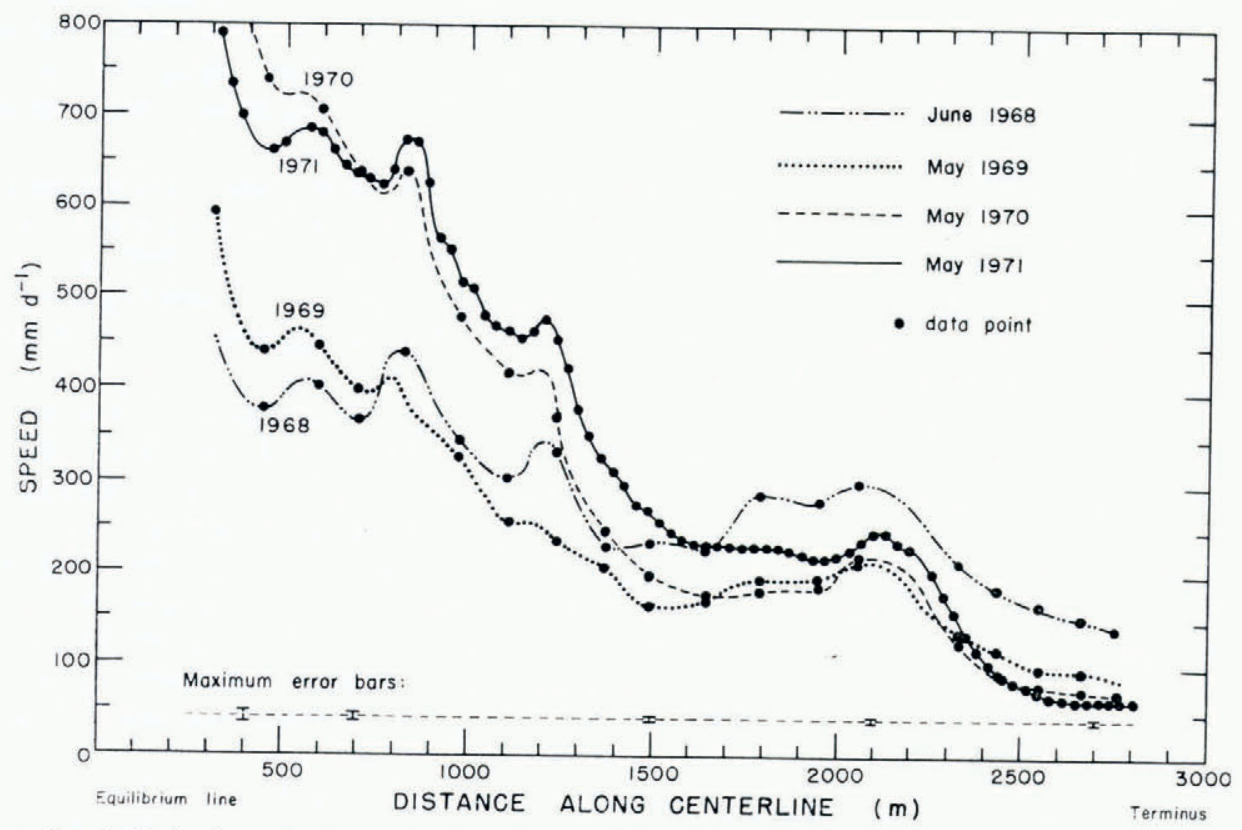

Fig. 15. Longitudinal velocity profiles for the four years 1968-7I. Each profile refers to approximately the same time of the year (the time of maximum velocity). The 1971 curve has been used to interpolate missing parts of the other curves. 
ablation area from 1969 to 1970 is apparent, but a similar increase from 1970 to 197 I did not occur. This suggests that the jökulhlaup, by suddenly releasing large amounts of water from within the glacier, was able to arrest the velocity increase (although apparently enough water was retained to maintain the velocity near the 1970 value). The permanent enlargement of crucial drainage channels could have prevented the storage of water from continuing. Other releases of water are known to have occurred, sometimes catastrophically, from the Nisqually Glacier in the past (Richardson, 1968) and they have also been observed from the Athabasca Glacier by Mathews ( $1964[\mathrm{a}]$ ).

Stored water was also released from Nisqually Glacier on 2 June I968, and on I4 July 1972. During the first release the stream gage recorder was damaged and during the second one it was destroyed completely, so it is not possible to verify that a gradual build-up followed by an abrupt drop in the discharge actually occurred, which is characteristic of a true jökulhlaup (Fig. 14). However, in both cases the total discharge during the floods was estimated to be several times greater than could be accounted for by snow melt and precipitation (personal communication from D. Richardson, 1972). Thus it seems certain that again some release of stored water must have taken place. All three floods occurred at the time of maximum liquid-water storage (Fig. I3). Furthermore, the total amount of water released was of the order of $\mathrm{I} \%$ of the glacier volume, the same as that estimated for the water storage at South Cascade Glacier. Such a large amount of water (equivalent to a layer approximately I $\mathrm{m}$ thick) must surely affect the motion of a glacier.

The data suggest that jökulhlaups are preceded by an abnormal increase in surface motion. Thus an obvious way to predict such floods would be to monitor the surface velocity, particularly near the equilibrium line.

Other evidence exists in the literature to support the idea that significant amounts of liquid water are stored in glaciers during the winter. Fisher (1963) describes an "enormous reservoir of water" encountered at the end of a tunnel drilled at $4000 \mathrm{~m}$ on the Breithorn. Contrary to his expectations the flow of water out of the tunnel "increased materially during the winter". Mathews ( $1964[\mathrm{~b}]$ ) made observations of the water level in a mine shaft which connected with the bed of South Leduc Glacier. He found some evidence for a "seasonal cycle in pressure"; "low base levels seemed to occur in late summer and higher base levels in winter". Röthlisberger (1972) has predicted theoretically that englacial water pressures should be higher in winter than in summer.

An additional implication concerning the storage of liquid water comes from the observation that the sliding contribution to the surface motion becomes progressively greater with distance up-glacier. For the uppermost stakes, near the equilibrium line, sliding accounts for over $90 \%$ of the motion. This suggests that relatively more water is stored higher up the ablation zone. Basal water pressures would therefore increase with distance up-glacier, a result which was also predicted by Röthlisberger (1972).

Possibly most of the liquid-water storage occurs near the equilibrium line; however, this may not be a general feature of glaciers since the equilibrium line on the Nisqually Glacier is topographically in a unique location, at the boundary between the steep upper half and the flatter lower half where the measurements were made. Nevertheless the storage of large quantities of water at this level on Mount Rainier is also suggested by the South Tahoma Glacier jökulhlaup of 3 I August 1967 , on the south-west flank of the mountain. Both aerial photographs and an eyewitness account indicate the water was released from the $2300 \mathrm{~m}$ level (Richardson, I968), the same elevation as the equilibrium line of the Nisqually Glacier. Two more floods have been released from the same point since 1967 (personal communication from A. S. Post, I972).

The seasonal wave can be explained qualitatively with this hypothesis. If there are larger amounts of water stored near the equilibrium line, the water pressure would be higher here than lower down the glacier. When melting commences in the spring, the critical pressure 
at which the passageways start to enlarge and connect up rapidly would therefore be reached sooner at higher elevations. The water which starts to drain down through the glacier would aid the enlargement of channels lower down. On the other hand, the seasonal wave in the minimum is probably a result of the longitudinal velocity gradient. Since the ice is always flowing faster higher up the glacier, the passageways would probably be closed off there before they would at lower elevations; the winter acceleration would commence sooner and the minimum would be sharper. This was indeed observed.

Could the seasonal wave be due to a kinematic wave in a thin film of water at the bed of the glacier? This was suggested by Weertman (1962) to explain the hourly and daily fluctuations of the surface speed of a glacier, but conceivably it might explain the seasonal wave as well. The wave speed would be about three times the velocity of the water in the film,

$$
c \approx \frac{d^{2} \rho g \sin \alpha}{4 \mu}
$$

where $d$ is the thickness of the film and $\mu$ is the viscosity of the water. Taking Weertman's values of $d=0.5 \mathrm{~mm}$ and $\mu=5.7 \times 10^{-16} \mathrm{bar}$ a, and $\alpha=14^{\circ}$ for the average slope of the Nisqually Glacier, this gives a wave speed of about $2000 \mathrm{~km} \mathrm{a}^{-1}$. Thus either this mechanism is not responsible for the seasonal wave or the thickness of the water film is an order of magnitude smaller. However, if the water film is made this thin $(0.05 \mathrm{~mm})$ to account for the seasonal wave then the controlling obstacle size can be no greater than $0.5 \mathrm{~mm}$ (Weertman, I 964) in order for the water film to affect the sliding speed by the amount $( \pm 25 \%)$ observed seasonally at the surface. This is at least an order of magnitude smaller than the controlling obstacle size calculated by Weertman. More recent theories of basal sliding (for example, Kamb, I970), might resolve this discrepancy.

Implicit in these conclusions is the assumption that the controlling parameter in the basal sliding mechanism is the englacial water pressure, or, more exactly, the "difference between the average normal stress at the ice interface and the water pressure in the passageways having access to the bed"' (Raymond, I971). Haefeli (1970), Lliboutry (1968) and Müller and Iken (1973) have also postulated this. The dependence of the basal sliding on the basal shear stress may well be masked by the effect of water at the bed. Thus it is understandable that Meier ( 1 968) was unable to correlate the sliding velocity with the basal shear stress on the Nisqually Glacier. The similar result of Paterson (1970) on the Athabasca Glacier is also expected. In fact, Paterson's suggestion that the sliding velocity might be correlated with the ice thickness is not unreasonable since thicker glaciers might be able to retain relatively more
stored water than thinner ones.

Obviously, simultaneous measurements of the sliding velocity and the liquid-water storage, or the englacial water pressure, are needed to confirm or deny the hypotheses proposed here. Existing theoretical models of a temperate glacier cannot adequately predict the motion since they use only observations of slope and thickness made at the surface and do not consider the effect of water at the bed.

Liquid-water storage appears to be crucial to an understanding, not only of the hydrology, but also of the dynamics of a temperate glacier. Jökulhlaups evidently represent the catastrophic release of stored water which has accumulated over a period of several years. Glacier surges, on the other hand, might be caused by a more gradual release, with large amounts of stored water being retained long enough to produce a spectacular advance of the terminus. Floods from a surging glacier have indeed been noted by Thorarinsson (1969).

\section{Acknowledgements}

This study was made as part of a doctoral dissertation in geophysics at the University of Washington (Hodge, I972, unpublished). I am indebted to Professor Mark Meier for guidance 
throughout the research and to Professor Norbert Untersteiner for providing the necessary financial support.

Permission to work on the Nisqually Glacier was granted by the National Park Service and the generous assistance of the staff of Mount Rainier National Park is greatly appreciated. The installation, maintenance and repeated calibration of the stream gage at the Nisqually River bridge was handled by the Glaciology Project Office, U.S. Geological Survey, Tacoma, Washington. Mr Donald Richardson performed the crucial discharge calculations.

The extensive field work was made possible by the assistance of over 80 individuals, and to each of them, my wife Susan, personal friends and employees of the National Park Service, the U.S. Geological Survey and the University of Washington, I wish to express my very sincere thanks.

This research was supported by the National Science Foundation through Contract GU-2655 and by the Office of Naval Research through Contract Nooor4-67-A-0103-0oo7. Support during preparation of the manuscript was provided by the U.S. Geological Survey.

MS. received ${ }_{1} 6$ February 1973 and in revised form 7 January 1974

\section{REFERENGES}

Agassiz, L. 1847. Nouvelles études et expériences sur les glaciers actuels, leur structure, leur progression et leur action physique sur le sol. Paris, Victor Masson. 2 vols.

Björnsson, H. [1972.] Bægisárjökull, north-Iceland. Results of glaciological investigations 1967-1968. Part I. Mass balance and general meteorology. Jökull, Ár 21, 1971, p. I-23.

Blümcke, A., and Finsterwalder, S. 1905. Zeitliche Änderungen in der geschwindigkeit der Gletscherbewegung. Sitzungsberichte der Mathematisch-physikalischen Klasse der K. Bayerischen Akademie der Wissenschaften zu München, Bd. 35 , Ht. I, p. IO9-3i.

Budd, W. F. 1970. The longitudinal stress and strain-rate gradients in ice masses. Fournal of Glaciology, Vol. 9, No. 55 , p. $19^{-27}$.

Fisher, J. E. 1963. Two tunnels in cold ice at $4,000 \mathrm{~m}$. on the Breithorn. Fournal of Glaciology, Vol. 4, No. 35, p. $5^{1} 3^{-20}$.

Forbes, J. D. 1846. Illustrations of the viscous theory of glacier motion. Philosophical Transactions of the Royal Society of London, Vol. $136, \mathrm{Pt} .2$, p. 143-210.

Glen, J. W. 1955. The creep of polycrystalline ice. Proceedings of the Royal Society of London, Ser. A, Vol. 228,

No. I 175 , p. $5^{1} 9^{-38}$.
Haefeli, R. 1970. Changes in the behaviour of the Unteraargletscher in the last 125 years. Fournal of Glaciology, Vol. 9, No. 56, p. 195-212.

Hodge, S. M. 197 I. A new version of a steam-operated ice drill. Fournal of Glaciology, Vol. I0, No. 6o, p. 387-93.

Hodge, S. M. 1972. The movement and basal sliding of the Nisqually Glacier, Mount Rainier. Scientific Report, Dept. of Atmospheric Sciences, University of Washington, Seattle, No. I 3.

Hodge, S. M. Unpublished. The movement and basal sliding of the Nisqually Glacier, Mount Rainier. [Ph.D. thesis, University of Washington, Seattle, Washington, 1972.]

Hoinkes, H. G. 1970. Methoden und Möglichkeiten von Massenhaushaltsstudien auf Gletschern. Ergebnisse der Messreihe Hintereisferner (Ötztaler Alpen) r953-1968. Zeitschrift für Gletscherkunde und Glazialgeologie, Bd. 6, Ht. I-2, p. 37-90.

Kamb, W. B. I970. Sliding motion of glaciers: theory and observation. Reviews of Geophysics and Space Physics, Vol. 8, No. 4, p. $673-728$.

Kamb, W. B., and Shreve, R. L. I966. Results of a new method for measuring internal deformation in glaciers. Transactions. American Geophysical Union, Vol. 47, No. 1, p. I9o. [Abstract.]

Lliboutry, L. A. 1968 . General theory of subglacial cavitation and sliding of temperate glaciers. Journal of

Glaciology, Vol. 7, No. 49, p. 2 I -58 .
Mathews, W. H. I959. Vertical distribution of velocity in Salmon Glacier, British Columbia. Fournal of Glaciology, Vol. 3 , No. 26, p. 448-54.

Mathews, W. H. rg64[a]. Discharge of a glacial stream. Organisation Météorologique Mondiale et Association Internationale d'Hydrologie Scientifique. Symposium. Eaux de surface, tenu à l'occasion de l'assemblée générale de Berkeley de l'Union Géodésique et Géophysique Internationale, $19-8-31-81963$, p. 290-300.

Mathews, W. H. 1964[b]. Water pressure under a glacier. Journal of Glaciology, Vol. 5, No. 38, p. 235-40.

Meier, M. F. 1960. Mode of flow of Saskatchewan Glacier, Alberta, Canada. U.S. Geological Survey. Professional Paper 351 .

. Calculations of slip of Nisqually Glacier on its bed: no simple relation of sliding velocity to shear stress. Union de Géodésie et Géophysique Internationale. Association Internationale d'Hydrologie Scientifique. Assemblée générale de Berne, 25 sept.-7 oct. 1967. [Commission de Neiges et Glases.] Rapports et discussions, p. 49-57. 
Meier, M. F., and others. 1974. Flow of Blue Glacier, Olympic Mountains, Washington, U.S.A., by M. F. Meier, W. B. Kamb, C. R. Allen and R. P. Sharp. Journal of Glaciology, Vol. 13, No. 68, p. $187-212$.

Müller, F. 1968. Mittelfristige Schwankungen der Oberflächengeschwindigkeit des Khumbugletschers am Mount Everest. Schweizerische Bauzeitung, Jahrg. 86, Ht. 31, p. 569-73.

Müller, F., and Iken, A. I973. Velocity fluctuations and water regime of Arctic valley glaciers. Union Géodésique et Géophysique Internationale. Association Internationale d'Hydrologie Scientifique. Commission de Neiges et Glaces. Symposium on the Hydrology of Glaciers, Cambridge, 7-13 September 1969, p. $1_{6} 6_{5}-82$.

Nye, J. F. 1952. The mechanics of glacier flow. Fournal of Glaciology, Vol. 2, No. 12, p. 82-93.

Nye, J. F. I953. The flow law of ice from measurements in glacier tunnels, laboratory experiments, and the Jungfraufirn borehole experiment. Proceedings of the Royal Society of London, Ser. A, Vol. 219, No. 1139, p. $477-89$.

Nye, J. F. 1965. The flow of a glacier in a channel of rectangular, elliptic or parabolic cross-section. Journal of Glaciology, Vol. 5, No. 41, p. 661-90.

Paterson, W. S. B. I969. The physics of glaciers. Oxford, etc., Pergamon Press. (The Commonwealth and International Library. Geophysics Division.)

Paterson, W. S. B. 1970. The sliding velocity of Athabasca Glacier, Canada. Journal of Glaciology, Vol. 9, No. 55, p. $55-63$.

Paterson, W. S. B., and Savage, J. C. 1963. Measurements on Athabasca Glacier relating to the flow law of ice. Journal of Geophysical Research, Vol. 68, No. 15, p. 4537-43. Raymond, C. F. 1971. Flow in a transverse section of Athabasca Glacier, Alberta, Canada. Fournal of Glaciology,
Vol. Io, No. 58, p. 55-84.

Raymond, C. F. Unpublished. Flow in a transverse section of Athabasca Glacier, Alberta, Canada. [Ph.D. thesis, California Institute of Technology, Pasadena, California, 1969.]

Richardson, D. 1968 . Glacier outburst floods in the Pacific Northwest. U.S. Geological Survey. Professional Paper 6oo-D, p. D79-D86.

Röthlisberger, H. I972. Water pressure in intra- and subglacial channels. Journal of Glaciology, Vol. I 1, No. 62, p. $177-203$.

Schimpp, O. ${ }^{1} 958$. Der Eishaushalt am Hintereisferner in den Jahren 1952-53 und r953-54. Union Géodésique et Géophysique Internationale. Association Internationale d'Hydrologie Scientifique. Assemblée générale de Toronto, 3-14 sept. 1957. Tom. 4, p. 301-14.

Shreve, R. L. 1972. Movement of water in glaciers. Journal of Glaciology, Vol. 11, No. 62, p. $205^{-14}$.

Shreve, R. L., and Sharp, R. P. I970. Internal deformation and thermal anomalies in lower Blue Glacier, Mount Olympus, Washington, U. S.A. Journal of Glaciology, Vol. 9, No. 55, p. $65-86$.

Stenborg, T. I970. Delay of run-off from a glacier basin. Geografiska Annaler, Vol. 52A, No. I, p. I-3o.

Tangborn, W. V., and others. In press. A comparison of glacier mass balance by glaciologic, hydrologic, and mapping methods, South Cascade Glacier, Washington, by W. V. Tangborn, R. M. Krimmel and M. F. Meier. Union Géodésique et Géophysique Internationale. Association Internationale d'Hydrologie Scientifique. Assemblée générale de Mcssou, I97I.

Thorarinsson, S. 1969 . Glacier surges in Iceland, with special reference to the surges of Brúarjökull. Canadian Fournal of Earth Sciences, Vol. 6, No. 4, Pt. 2, p. 875-82.

[Union Géodésique et Géophysique Internationale.] ${ }^{1} 963$. Colloque d'Obergurgl (suite). Bulletin de l'Association Internationale d'Hydrologie Scientifique, 8 e An., No. 2, p. 50-1 42.

Weertman, J. 1962. Catastrophic glacier advances. Union Géodésique et Géophysique Internationale. Association Internationale d'Hydrologie Scientifique. Commission des. Neiges et des Glaces. Colloque d'Obergurgl, I0-9-18-9 1962 p. $31-39$.

Weertman, J. 1964. The theory of glacier sliding. Fournal of Glaciology, Vol. 5, No. 39, p. $287-303$. 